\title{
ANALYSIS OF MEDICAL ASSISTANCE PROVIDED TO SPECTATORS AT THE 2014 FIFA WORLD CUP MATCHES
}

\section{ANÁLISE DA ASSISTÊNCIA MÉDICA PRESTADA AOS ESPECTADORES NOS JOGOS DA COPA DO MUNDO DA FIFA DE 2014}

\author{
Gustavo Gonçalves Arliani ${ }^{1}$, Paulo Henrique Schmidt Lara ${ }^{1}$, André Pedrinelli² ${ }^{2}$ Benno Ejnisman ${ }^{1}$, Luiz Marcelo Bastos Leite ${ }^{1}$, \\ MOISES COHEN ${ }^{1}$
}

1. Center of Sports Traumatology, Departament of Orthopedics and Traumatology at the Universidade Federal de São Paulo, SP, Brazil.

2. Institute of Orthopedics and Traumatology at the Hospital das Clinicas, Faculdade de Medicina da Universidade de São Paulo, SP, Brazil.

\begin{abstract}
Objective: Several studies have already described the main injuries to soccer players during FIFA World Cup events; however, little is known about the main reasons spectators require medical assistance during these matches. The aim of this study is to assess the number of cases and main reasons spectators required medical assistance during the 2014 World Cup matches in Brazil. Methods: Data were collected from spectators who received medical assistance on all game days, and factors related to the assistance provided were analyzed. Results: Medical assistance was given to spectators in a total of 6,222 cases during the 64 games played in Brazil, an average of 97.2 times per game. The total number of spectators removed from the stadiums by ambulance was 167, a mean of 2.6 removals per game. The main reasons spectators required medical assistance during the World Cup games were headache, gastrointestinal problems, and trauma. Conclusions: Most spectators required medical assistance during the World Cup games for headache, gastrointestinal problems, and trauma; this information is fundamental to develop new prevention strategies and plan medical assistance for large-scale events. Level of Evidence IV; Case series.
\end{abstract}

Keywords: Soccer. Medical assistance. Sports medicine.

\section{RESUMO}

Objetivo: Vários estudos já descreveram as principais lesões dos jogadores de futebol durante os eventos da Copa do Mundo da FIFA; entretanto, pouco se sabe sobre as principais razões para assistência médica aos espectadores durante as partidas. O objetivo deste estudo é avaliar o número de casos e as principais razões pelas quais os espectadores necessitaram de assistência médica durante os jogos da Copa do Mundo de 2014 no Brasil. Métodos: Foram coletados dados dos espectadores que receberam assistência médica durante todos os dias de jogos e os fatores relacionados ao atendimento foram analisados. Resultados: A assistência médica foi prestada aos espectadores em 6.222 casos durante os 64 jogos no Brasil, com média de 97,2 assistências por jogo. O número total de remoções com ambulância foi de 167, com média de 2,6 remoções por jogo. As principais razões para a assistência médica durante os jogos da Copa do Mundo foram cefaleia, problemas gastrintestinais e trauma. Conclusões: A maioria dos espectadores precisou de assistência médica durante os jogos da Copa do Mundo em decorrência de cefaleia, problemas gastrintestinais e trauma; essa informação é fundamental para o desenvolvimento de novas estratégias de prevenção e planejamento de assistência médica em eventos de massa. Nível de Evidência IV; Série de casos.

Descritores: Futebol. Assistência médica. Medicina esportiva.

Citation: Arliani GG, Lara PHS, Pedrinelli A, Ejnisman B, Leite LMB, Cohen M. Analysis of medical assistance provided to spectators at the 2014 fifa world cup matches. Acta Ortop Bras. [online]. 2018;26(1):33-5. Available from URL: http://www.scielo.br/aob.

\section{INTRODUCTION}

The FIFA World Cup, one of the most popular sporting events, is watched on television by millions of people who, in turn, try to mimic the performance of football stars. ${ }^{1}$

Before the World Cup, approximately 10,000 health professionals were trained to act during the tournament. In addition to the plans for providing medical assistance to the spectators, contingency plans were also made for accidents with mass casualties and for scenarios with chemical, biological, radiological and nuclear products. ${ }^{2}$
The past history of accidents and catastrophes related to football matches shows the importance of practical and theoretical planning, preparation, simulation training and analysis of possible patient causes to guarantee the safety and good care of the public during the games in the event. ${ }^{3,4}$ A detailed analysis of the causes of medical assistance to spectators during FIFA World Cup is helpful so that possible trends can be better understood and prevention strategies can be developed. ${ }^{4}$ The objective of the present study was to show the numbers and main causes of medical assistance to spectators throughout the matches during the 2014 World Cup games in Brazil.

All authors declare no potential conflict of interest related to this article.

Work conducted at the Center of Sports Traumatology, Departament of Orthopedics and Traumatology at the Federal University of São Paulo, SP, Brazil. Correspondence: Paulo Henrique Schmidt Lara. Rua Estado de Israel, 636, Vila Clementino, São Paulo, SP, Brasil. 04022-001. phslara@gmail.com 


\section{METHODS}

This is a descriptive study with data collected from spectators who received medical assistance at the stadiums' medical rooms during the 64 games of the FIFA World Cup in 2014 in Brazil. Each medical station was trained and prepared to offer emergency medical assistance to spectators, players, and staff from three hours prior to until one hour after the matches. During the games, each of the 12 stadiums had medical stations. A patient record form was used to capture data related to medical assistance. Whenever necessary, the patients were transferred by ambulances to a predetermined referral hospital. This form was developed and approved prior to the tournament. At the end of each game, all the information and data collected were gathered and analyzed by the local medical coordinators.

The patient record forms were filled out by approximately 300 physicians who had received training prior to the World Cup. The data accumulated from all the 64 games played in Brazil included: (1) total number of spectators; (2) total number of assistances; (3) total number of removals; (4) public present in each stadium; (5) disease /injury categories cared for; (6) disease /injury categories transfer to the hospital; (7) relationship between public assistance and tournament phase; (8) relation between number of removals and tournament phase; (9) local accommodation rate. The information about the total number of spectators and public present in each stadium was provided by the local organizing committee (LOC).

The local accommodation rate was defined as the number of spectators per game compared to the maximum capacity for spectators in the stadiums. The patient care rate was defined as the number of patients per 1000 spectators per game. The hospital removal rate was defined as the number of patients transported to hospital by ambulance per 1000 spectators per game. Removal was defined as patients that were transferred to further medical management at a referral hospital. The following disease and injury categories were used: Neurology/ Cephalea; Gastrointestinal Symptoms; Trauma; Dehydration; Myalgia; Cardiovascular Symptoms; Otorhinolaryngology /Ophthalmology; Dermatology; Respiratory Symptoms; Gynecology/ Obstetrics; Odontology and Urinary Symptoms.

The first phase of the tournament was considered the phase that each of the teams played three group matches and the second phase was considered from the round of 16 stage until the final match.

A mean value and standard deviation for each of the variables were calculated. These statistical analyses were made using the SPSS for Windows program, version 16.0. Statistical methods applied were frequencies, cross-tabulations and $x^{2}$ test. Significance was accepted at $5 \%$ level. The Ethics and Research Committee of Federal University of São Paulo approved this study (IRB 1319/10).

\section{RESULTS}

During the 2014 FIFA World Cup, 12 cities hosted the matches. The number of matches at each host city is listed in Table 1.

The total number of spectators at the 64 games of the tournament was $3,443,335$ and the average attendance per game was 53,802 spectators. The local accommodation rate in the tournament was 91,9 $\%$. The average attendance in the second phase of the tournament was 60,967 spectators, which was significantly greater than the average of 51,414 spectators in the first phase. ( $p=0,0065)$

The total number of medical assistance to spectators during the 64 games in Brazil was 6,222, with an average of 97,2 medical assistances per game. The mean age of patients was 31,7 years old (1-79). The division of medical assistance to spectators by gender during the tournament was 53,7 \% male and 46,3 \% female. The total number of patients who required removal was 167 (2,7\% of the total), with a mean of 2,6 removals per game. The patient care rate during the tournament was 1,82 . The removal rate of patients to hospital was 0,05 .
The main causes for medical assistance during the World Cup games were neurology/cephalea, gastrointestinal problem and traumas. (Table 2)

The medical categories for removal are shown in Table 3.

The comparison between public, assistance and removals according to the phase of the games is shown in Table 4.

\section{DISCUSSION}

The present study, in addition to presenting the indices and main causes of medical assistance to spectators and removal during the 2014 FIFA World Cup, demonstrated differences in these indices in the two phases of the tournament showing the importance of the medical care and spectators assistance in the last games of the championship. The patient assistance rate during the tournament was 1,824. Slightly lower rates were found by Morimura et al. ${ }^{5}$, but it was within the range found in previous studies ${ }^{4,5}$. De Lorenzo et al. ${ }^{6}$ reported that the rate of patient assistance in mass events varies from 0,14 to 19 patients per 1000 spectators. Possible factors related to the slightly large patient assistance rate include: larger public, greater local accommodation rate and the importance of the game..$^{7-9}$

\begin{tabular}{c|c}
\hline \multicolumn{2}{|c}{ Table 1. Number of games at the 12 World Cup host cities. } \\
\hline Host Cities & $7(10.9 \%)$ \\
\hline Brasilia & $7(10.9 \%)$ \\
\hline Rio de Janeiro & $6(9.4 \%)$ \\
\hline Belo Horizonte & $6(9.4 \%)$ \\
\hline Fortaleza & $6(9.4 \%)$ \\
\hline Salvador & $6(9.4 \%)$ \\
\hline São Paulo & $5(7.8 \%)$ \\
\hline Porto Alegre & $5(7.8 \%)$ \\
\hline Recife & $4(6.3 \%)$ \\
\hline Cuiabá & $4(6,3 \%)$ \\
\hline Curitiba & $4(6.3 \%)$ \\
\hline Manaus & $4(6,3 \%)$ \\
\hline Natal & $64(100 \%)$ \\
\hline Total &
\end{tabular}

Table 2. Main causes for medical assistance during the World Cup games.

\begin{tabular}{c|c|c}
\hline Causes for medical assistance & $\mathrm{n}$ & $\%$ \\
\hline Neurology/Cephalea & 1973 & 31.7 \\
\hline Gastrointestinal Symptoms & 941 & 15.1 \\
\hline Trauma & 932 & 15.0 \\
\hline Dehydration & 645 & 10.4 \\
\hline Myalgia & 459 & 7.4 \\
\hline Cardiovascular Symptoms & 328 & 5.3 \\
\hline Otorhinolaryngology /Ophthalmology & 349 & 5.6 \\
\hline Dermatology & 191 & 3.1 \\
\hline Respiratory Symptoms & 196 & 3.1 \\
\hline Gynecology/Obstetrics & 138 & 2.2 \\
\hline Odontology & 54 & 0.8 \\
\hline Urinary Symptoms & 16 & 0.3 \\
\hline Total & 6222 & 100
\end{tabular}

Table 3. Main causes of hospital removals during the games.

\begin{tabular}{c|c|c}
\hline Causes of hospital removals & $\mathbf{n}$ & $\%$ \\
\hline Trauma & 62 & 37.1 \\
\hline Neurology/Cephalea & 33 & 19.7 \\
\hline Cardiovascular Symptoms & 21 & 12.6 \\
\hline Gastrointestinal Symptoms & 17 & 10.2 \\
\hline Myalgia & 9 & 5.4 \\
\hline Dehydration & 8 & 4.8 \\
\hline Urinary Symptoms & 6 & 3.6 \\
\hline Respiratory Symptoms & 6 & 3.6 \\
\hline Gynecology/Obstetrics & 2 & 1.2 \\
\hline Dermatology & 2 & 1.2 \\
\hline Otorhinolaryngology/Ophthalmology & 1 & 0.6 \\
\hline Odontology & 0 & 0 \\
\hline Total & 167 & 100 \\
\hline
\end{tabular}


Table 4. Public, assistance and removals according to the phase of the games in the 2014 World Cup.

\begin{tabular}{|c|c|c|c|}
\hline & \multicolumn{2}{|c|}{ Phase } & \multirow{2}{*}{$\begin{array}{c}\text { Combined } \\
\text { Average }\end{array}$} \\
\hline & First & Second & \\
\hline & $(n=48)$ & $(n=16)$ & $(n=64)$ \\
\hline \multicolumn{4}{|l|}{ Attendance per game } \\
\hline Average (SD) & $51413.9(12134.7)$ & $60966.6(10392.8)$ & $53802.1(12367.4)$ \\
\hline Minimum - Maximum & $37603-74738$ & $41242-74738$ & $37603-74738$ \\
\hline$p$-value & \multicolumn{2}{|c|}{0.0065} & \\
\hline \multicolumn{4}{|l|}{$\begin{array}{c}\text { Medical assistance } \\
\text { per game }\end{array}$} \\
\hline Average (SD) & $86.8(40.3)$ & $128.6(46.9)$ & $97.2(45.5)$ \\
\hline Minimum - Maximum & $27-198$ & $54-222$ & $27-222$ \\
\hline $\mathrm{p}$-value & \multicolumn{2}{|c|}{0,001} & \\
\hline \multicolumn{4}{|l|}{ Patient care rate $(\% \circ)$} \\
\hline Average (SD) & $1.70(0.69)$ & $2.17(0.91)$ & $1.82(0.77)$ \\
\hline Minimum - Maximum & $0.69-3.25$ & $0.79-4.36$ & $0.69-4.36$ \\
\hline$p$-value & \multicolumn{2}{|c|}{0,0315} & \\
\hline \multicolumn{4}{|l|}{ Removals per game } \\
\hline Average (SD) & $2.4(1.5)$ & $3.3(1.4)$ & $2.6(1.5)$ \\
\hline Minimum - Maximum & $0-7$ & $1-5$ & $0-7$ \\
\hline$p$-value & \multicolumn{2}{|c|}{0,0289} & \\
\hline \multicolumn{4}{|l|}{ Removal rate $(\%)$} \\
\hline Average (SD) & $0.05(0.04)$ & $0.06(0.02)$ & $0.05(0.03)$ \\
\hline Minimum - Maximum & $0.00-0.17$ & $0.02-0.09$ & $0.00-0.17$ \\
\hline $\mathrm{p}$-value & \multicolumn{2}{|c|}{ n.s. } & \\
\hline $\begin{array}{c}\%: \text { per thousand } \\
\text { à } 1 \% \circ=0,1 \%\end{array}$ & & & \\
\hline
\end{tabular}

The present study found differences in the medical assistance rates between the two phases of the World Cup, with the final phase of the tournament having the greatest medical assistance rates. Other studies, however, have not reported a relationship between the number of medical assistances and total number of spectators. ${ }^{4,10}$ Other factors may be important in increasing the number of medical assistance to spectators at major sporting events such as: consumption of alcohol, public education and high temperatures/weather during the matches. However, Burton et al. ${ }^{11}$ found that alcohol was a contributing factor in only $5 \%$ of medical assistances in rugby matches and horse races in the United Kingdom. The local accommodation rate in the tournament was 91,9\%. Morimura et al. ${ }^{5}$ reported a lower number (89\%) in the 2002 Japan/Korea FIFA World Cup. This rate is an indicator of the public concentration and may have influenced the greater assistance rate found in the present study. Milsten et al. ${ }^{12}$ also demonstrated that public density contributed to the number of patients treated at an event.

The patient hospital removal rate was 0,05 in the present study. Morimura et al. ${ }^{5}$ reported a similar rate in the Japan/Korea World
Cup $(0,03$ removals). The total number of patients taken to hospital in Brazil was 167 (2,7\% of the total). The 2002 FIFA World Cup presented a higher percentage of removals, with $4,4 \%$ of the total of patients assisted being removed to referral hospitals. ${ }^{5}$

The main causes of medical assistance and removal during the games were neurology/cephalea, gastrointestinal problems, trauma and cardiovascular problems. Similar findings were reported in another study that the main causes of medical assistance were trauma, headache and abdominal symptoms. ${ }^{7}$ Most cases treated during the games did not need removal to hospitals. However, an epidemiological analysis is extremely important in order to plan medical activities, especially in more severe cases that need more care. Nowadays, there is a growing recognition that good historical data for a specific event or type of event can help to forecast medical requirements. ${ }^{13,14}$ In the present study, no difference was found between the two phase of the championship in the patient removal rate. The reason for this phenomenon is unknown, and extra data collection and analyses would be necessary in future studies.

A limitation of the study was that the standard determined for disease and injury classification was not the same as that used in previous studies and severity of illnesses was not measured. The disease and injury classification should be standardized in epidemiological studies of the FIFA World Cups, so that the data can be compared and analyzed in a more precise manner. ${ }^{3}$ Another limitation was the difficulty to follow the outcomes of the patients removed to hospital and to identify alcohol as a factor associated to trauma injuries. A final limitation is the variability in documentation among the many physicians. This study showed medical assistance rate to spectators similar to previous studies but found differences between the two phases of the World Cup, with the final phase of the tournament having the greatest medical assistance rates. This difference hadn't been found in previous studies. This information is fundamental in the development of new prevention strategies and planning medical assistance at mass events.

\section{CONCLUSION}

The main causes for medical spectators assistance during the World Cup games were neurology/cephalea, gastrointestinal problem and trauma. There were statistically significant differences between the first and second phases with respect to total attendance per game, number of medical assistance to spectators per game, patient care rate, and number of patients that required removal per game. The results of the present study also offer an opportunity to follow long-term alteration in the frequency and circumstances of medical assistance at future FIFA World Cups.

AUTHORS' CONTRIBUTIONS: Each author made significant individual contributions to this manuscript. GGA (0000-0003-4371-5041)*: collected the data, wrote and reviewed the article, and analyzed the data; PHSL (0000-0002-1623-2071)*: collected the data, wrote and reviewed the article, analyzed the data, and performed the statistical analysis. AP (0000-0002-8449-7493)*: wrote and reviewed the article; BE (0000-0002-3301-1457) ${ }^{\star}$ : wrote and reviewed the article and analyzed the data; LMBL (0000-0001-6324-7797)*: wrote and reviewed the article; MC (0000-0001-7671-8113)*: wrote and reviewed the article and contributed to the intellectual concept of the study and the entire research project. *ORCID (Open Researcher and Contributor ID).

\section{REFERENCES}

1. Junge A, Dvo ák J. Football injuries during the 2014 FIFA World Cup. Br J Sports Med. 2015;49(9):599-602.

2. Shoaf K, Osorio de Castro CG, Miranda ES. Hospital preparedness in advance of the 2014 FIFA World Cup in Brazil. Prehosp Disaster Med. 2014;29(4):409-12.

3. Lablanc ML, Henshaw R. Disasters and Tragedies. The world encyclopedia of soccer. 2nd ed. Detroit: Visible Ink Press;1994.

4. Jaslow D, Yancy A 2nd, Milsten A. Mass gathering medical care. National Association of EMS Physicians Standards and Clinical Practice Committee. Prehosp Emerg Care. 2000;4(4):359-60.

5. Morimura N, Katsumi A, Koido Y, Sugimoto K, Fuse A, Asai Y, et al. Analysis of patient load data from the 2002 FIFA World Cup Korea/Japan. Prehosp Disaster Med. 2004;19(3):278-84.

6. De Lorenzo RA. Mass gathering medicine: a review. Prehosp Disaster Med. 1997;12(1):68-72

7. Franaszek J. Medical care at mass gatherings. Ann Emerg Med. 1986;15(5):600-1.

8. Michael JA, Barbera JA. Mass gathering medical care: a twenty-five year review. Prehosp Disaster Med. 1997;12(4):305-12

9. Zeitz KM, Schneider DP, Jarrett D, Zeitz CJ. Mass gathering events: retrospective analysis of patient presentations over seven years. Prehosp Disaster Med. 2002; 17(3):147-50

10. Arbon $\mathrm{P}$, Bridgewater FH, Smith $\mathrm{C}$. Mass gathering medicine: a predictive model for patient presentation and transport rates. Prehosp Disaster Med. 2001;16(3):150-8.

11. Burton JO, Corry SJ, Lewis G, Priestman WS. Differences in medical care usage between two mass-gathering sporting events. Prehosp Disaster Med. 2012;27(5):458-62.

12. Milsten AM, Maguire BJ, Bissell RA, Seaman KG. Mass-gathering medical care a review of the literature. Prehosp Disaster Med. 2002;17(3):151-62

13. Zeitz KM, Zeitz CJ, Arbon P. Forecasting medical work at mass-gathering events: predictive model versus retrospective review. Prehosp Disaster Med. 2005;20(3):164-8.

14. Hartman N, Williamson A, Sojka B, Alibertis K, Sidebottom M, Berry T, et al. Predicting resource use at mass gatherings using a simplified stratification scoring model. Am J Emerg Med. 2009;27(3):337-43. 